\title{
DIE GEOMETRIESE EN RIVIERGRENSE VAN SUIDWES-AFRIKA, MET SPESIALE VERWYSING NA DIE NOORDE EN DIE CAPRIVISTROOK
}

\author{
Kol J.C. Kotzé*
}

\begin{abstract}
In this article it becomes evident that the boundaries of Southwest Africa and especially the Northern and Caprivi boundaries are arbitrary and artificial.
\end{abstract}

Human decision-making, although many years ago, created this unnatural situation whereby people speaking the same language and often engaging in the same economic activities, were separated from each other. Separations where economical, ethnic and linguistic factors are not taken into account, occur worldwide and is not a problem restricted to the boundaries of Africa.

\section{Inleiding}

Met 'n oppervlakte van $824269 \mathrm{~km}^{2}$ beklee SWA/Namibië, wat grootte-orde betref, die vyftiende posisie op die vasteland van Afrika. Die inwonertal word tans op 1150000 gestel en plaas hierdie land op een na, laaste op die bevolkingsdigtheidskaal van die kontinent.

Suidwes-Afrika het gedurende die laaste dekades van die vorige eeu as 'n staatkundig-gedefinieerde gebied tot stand gekom. Dit was die gevolg van onderhandelings en grensreëlings tussen Brittanje, Duitsland en Portugal. Lank voor hierdie tydperk het ontdekkingsreisigers egter vlugtig met hierdie geïsoleerde deel van Afrika kennis gemaak. Portugese seevaarders soos Diego Caō (1484), Bartolomeus Diaz (1486) en Gasper Vegas (1534) het almal baie kortstondig en oppervlakkig met hierdie landstreek kennis gemaak. Na die vestiging van Blankes aan die Kaap (1652) is skepe op verskillende geleenthede van daar gestuur om die Suidwes-Afrikaanse kus te verken. In die 18de en 19de eeu het jagters en reisigers toenemend die gebied binnegedring en inligting oor die land en sy mense bekom. Anneksasie-aksie het ook nie agterweë gebly nie. In 1793 is 'n skip die "Meermin" vanaf die Kaap gestuur om Nederlandse soewereiniteit oor Angra Pequena, Halifax-eiland en Walvisbaai te proklameer. Met die Britse oorname van die Kaap in 1795 is ' $n$ vaartuig die "Star" ook gestuur om die Britse vlag by al die aandoenplekke langs die weskus tot so ver as Angola te hys.

Die bedrywighede van handelaars en sendelinge het die gebied toenemend aan die buitewêreld bekend gestel. Onbekende dele is ook deur die ontdekkingsreise van persoonlikhede soos James Alexander (1836-37), sir Francis Galton en Charles John Anderson (1851), James Chapman (1855), ens oopgestel. Anderson wat ook tussen 1859 en 1867 verkenningstogte in die land onderneem het, het veral die ylbewoonde Kaokoveld, Ovamboland en Okavango bekendgestel en het alreeds in sy geskrifte na hierdie groot gebied as Suidwes-Afrika verwys.

Die ryk ghwano-eilande langs die Suidwes-Afrikaanse kus is tussen 1861-1866 deur die Kaapse regering in besit geneem. Werklike gesagsvestiging het egter in 1878 werklikheid geword toe kommandeur R.C. Dyer die Walvisbaaigebied in naam van die Britse koningin geannekseer het. Hierdie gebied is in 1884 (Wet no 35 ) by die Kaapkolonie ingelyf (Odendaal $1964 ; 8)$.

Reeds in Julie 1883 was dit in Londen bekend dat 'n Duitser, Heinrich Vogelsang, as verteenwoordiger van Adolf Lüderitz, 'n handelaar van Bremen, te Angra Pequena geland het. Politieke verwikkelinge het daartoe gelei dat die Duitse konsul aan die Kaap die Kaapse regering in April 1984 verwittig het dat die gebied rondom Angra Pequena formeel onder Duitse beskerming geplaas is. Die baai is tot Lüderitzbucht vernoem en die Duitse vlag is amptelik op 7 Augustus 1884 op die strand gehys. Duits-SuidwesAfrika is op die wyse gebore. Verdere vlaghysingseremonies langs die kus en anneksasies sou kort daarna volg (Odendaal 1964; 10 en Stals 1985; 39).

Gebeure in Afrika tussen 1884 en die laat 1890's het die karakter van ' $n$ koorsagtige gegryp deur Europese moondhede na beskikbare grondgebied gedra. Duitsland self het aan hierdie "stormloop" of "verdeling van Afrika" meege- 
doen en op die wyse vier kolonies $\mathrm{nl}$ Kameroen, Togo, Oos-Afrika (Tanganjika) en Suidwes-Afrika bekom. Hierdie kolonisasiepoging het oor minder as twee jaar gestrek - vanaf Julie 1884 tot Desember 1885! (Stals 1985; 32, 33).

Die Lüderitzbuchtgebied, die kusstrook vanaf die Oranjeriviermond tot by Kaap Frio (met uitsluiting van die Walvisbaaigebied) en Namaland is opeenvolgend gedurende 1884 as Duitse protektorate verklaar. In September 1885 is ooreenkomste ook met die Rooinasie (Nama) en die Rehoboth-Basters gesluit, terwyl ook die $\mathrm{He}$ roro's in Oktober van dieselfde jaar Duitse beskerming aanvaar het. Duitsland het dus sy invloedsfeer al dieper die binneland in uitgebrei. Teen 1886 was hierdie harde, droë, maar bykans ongerepte land, afgesien van sy lang Atlantiese kuslyn deur grondgebied wat onderskeidelik in die noorde aan Portugal en in die ooste en suide aan Brittanje behoort het, begrens. Grensverdrae wat met Portugal (1886) en Brittanje (1890) gesluit is, het formele beslag aan die ruimtelike omvang van Duits-SuidwesAfrika verleen (Odendaal 1964; 10 en Stals 1985; 39).

Duitse gesag in Suidwes-Afrika het op 9 Julie 1915 tydens die Eerste Wêreldoorlog ten einde geloop toe die Duitse troepe in die land die knie voor die Suid-Afrikaanse magte moes buig. Met die ondertekening van die Verdrag van Versailles op 28 Junie 1919 het Duitsland van sy kolonies in Afrika, oa Duits-Suidwes-Afrika afstand gedoen. Kragtens hierdie verdrag is hierdie gebied as 'n C-mandaat verklaar en aan Suid-Afrika as mandateris van die ou Volkerebond toevertrou. Deur die Zuid West Afrika Mandaat Wet (Wet no 49/1919), wat deur die Unieparlement aanvaar is, het Suid-Afrika dus formeel verantwoordelikheid vir hierdie mandaat aanvaar (Odendaal 1964; 10 en Wellington 1967; 263). In 1946, na afloop van die Tweede Wêreldoorlog, het Suid-Afrika as mandaathouer geweier om 'n nuwe voogdyskapsooreenkoms met die VVO aan te gaan. Die algemene vergadering van hierdie organisasie het in resolusie 2145 (XXI) van 27 Oktober 1966 die mandaat beëindig en verklaar dat Suidwes-Afrika die direkte verantwoordelikheid van die VV was. Hierdie besluit is egter deur die RSA as onwettig verwerp. Suid-Afrika het geweier om sy administrasie van die mandaatgebied te beëindig. (Van der Spuy 1977; 941). Deur middel van resolusie 2372 van 12 Junie 1968 is die naam Namibië ook vir die gebied aanvaar (Brownlie 1979; 1026).
Ondanks talle samesprekings kon hierdie wêreldliggaam nog nie daarin slaag om tot ' $n$ vergelyk met die RSA oor Suidwes-Afrika te kom nie. Die de jure-posisie is tans dat hierdie land deur ' $n$ VV-raad vir Namibië, bygestaan deur ' $n$ uitvoerende kommissaris regeer word. Die de facto-situasie is egter dat die RSA dmv ' $n$ administrateur-generaal en ' $n$ oorgangsregering die land regeer (Rake 1984; 94 en Europa Pubs 1985; 705).

\section{Die grense van Suidwes-Afrika}

Die grense van Suidwes-Afrika is reeds voor die einde van die 19de eeu bepaal toe Duitsland ooreenkomste met die moondhede wat gesag oor die aangrensende kolonies uitgeoefen het, gesluit het. Weinig grensveranderinge het sedertdien plaasgevind. Die vasstelling van hierdie grense het dus per implikasie die gebied waaroor Suidwes-Afrika as politieke eenheid jurisdiksie en gesag kan uitoefen, aangedui en die kontaklyne tussen hierdie staat en sy bure bepaal (Pfaff 1985; 65).

In totaal beslaan die Suidwes-Afrika-grense 5304 kilometer. Hiervan is 1484 kilometer onderskeidelik seegrense, 2280 kilometer geometriese grense en 1540 kilometer riviergrense. Verskillende verdrae het wetlike beslag aan die onderskeie landsgrense verleen. Die suid- en oosgrens, die noordgrens en die Walvisbaai-gebied (wat deel van die RSA vorm) is onderskeidelik deur 'n Anglo-Duitse verdrag van 1 Julie 1890, 'n Duits-Portugese deklarasie van $30 \mathrm{De}$ sember 1886 en die anneksasie-proklamasie van kommandeur Richard C. Dyer van 12 Maart 1978 bepaal. Al die neergelegde grensbepalings besit nog volle geldigheid (Barnard 1959; 220).

Indien die lang kuslyn buite rekening gelaat word blyk dit dat bykans $60 \%$ van die landgrense van Suidwes-Afrika geometries van aard is. Die vasstelling van grense op die wyse was 'n algemene gebruik op die vasteland van Afrika. Hierdie prosedure was te wyte aan die haas waarmee grense teen die einde van die vorige eeu bepaal moes word asook die gebrekkige geografiese kennis waaroor die verdragmakers beskik het. Terselfdertyd het hierdie tipe grense die voordeel ingehou dat hul gou en akkuraat op kaart vasgestel kon word en redelik maklik in die landskap afgebaken kon word (Kyk Pfaff 1985; 66). Dat hierdie vasstellingsmetode nie sonder probleme was nie spreek duidelik uit Lord Salisbury se verklaring wat lui: 
"We have been engaged in drawing lines upon maps where no White man's foot has ever trod; we have been giving away mountains and rivers and lakes to each other, only hindered by the small impediment that we never knew exactly where the mountains and rivers and lakes were" (Kyk Prescott 1979: 5).

Alhoewel hierdie stelling nie op alle SuidwesAfrikaanse grense van toepassing is nie het baie ander egter nie hierdie leemtes ontkom nie.

By die ou verdragopstellers was riviergrense byna net so gewild as geometriese grense. Ook hier was die rede voor-die-handliggend. Reisigers het dit maklik gevind om riviere eerder as ander topografiese gegewens op kaart aan te bring. Terselfdertyd is dit as lynvormige verskynsels gevisualiseer wat as akkurate verdelingslyne gebruik kon word. Tog is riviere in werklikheid sones en nie ' $n$ enkelvoudige lyn nie. Grensvasstellings kan dus op verskillende maniere plaasvind. Riviergrense kan dus ò die mediaanlyn òf die bevaarbare kanaal of een van die oewers of verskillende vaste punte ("running points") wat in die stroom bepaal word volg. Normaalweg volg grense die hoofkanaal of "thalweg" wanneer die rivier bevaarbaar is. Indien nie, word die mediaan- of swaartelynbeginsel gevolg (Pounds 1972; 88).

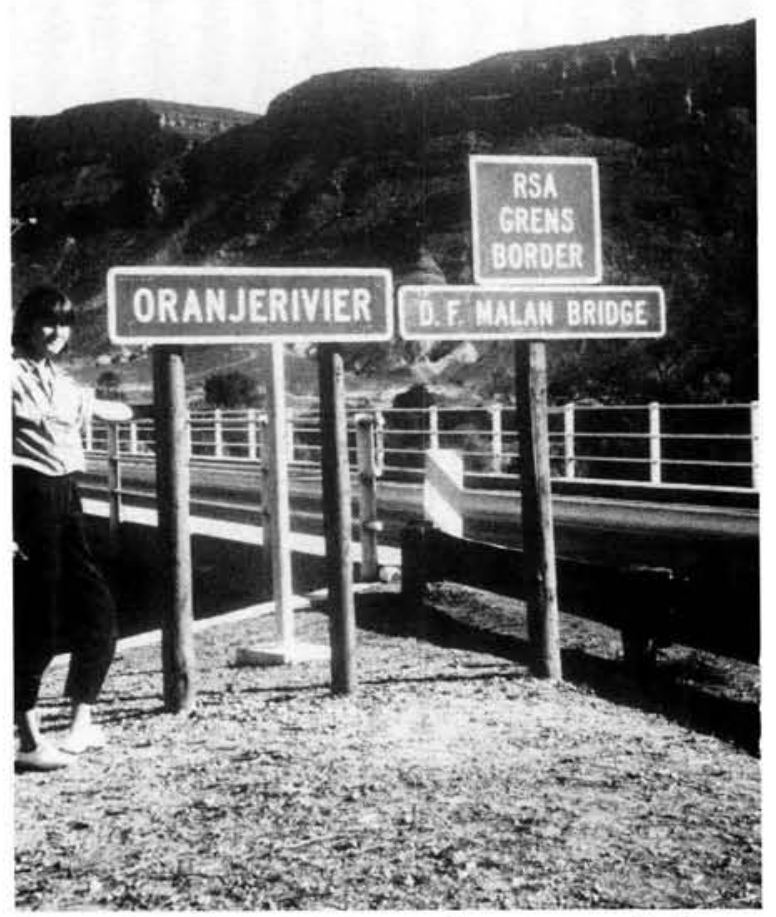

Die Oranjerivier vorm die suidelike grens van SuidwesAfrika. Hier volg die grens die noordoewer van die rivier.
Wanneer slegs die naam van ' $n$ rivier as grens in Suidwes-Afrika se geval genoem word, was die bedoeling dat dit die middel van die hoofstroom moes wees. In die geval van die Oranjerivier is egter van hierdie beginsel afgewyk want die grens is langs die noordoewer geleë. ' $n$ Oewer kan omskryf word as die gemiddelde hoogwatermerk tydens normale someroorstromings (Die seisoen waarin die grootste neerslag aangeteken word). So 'n grens is baie ingewikkeld omdat dit talle kronkelinge en draaie het wat selfs op 'n grootskaalkaart moeilik akkuraat verbeeld kan word.

Hierdie onpraktiese grensreëling impliseer dus dat Suidwes-Afrika in teorie geen aanspraak op die water van die Oranjerivier kon maak nie. Die praktyk toon egter dat beide die landbou (Wes van Vioolsdrif) en die mynbou (Oranjemund) Oranjerivierwater benut (Barnard 1959; 234).

Die haas waarmee Afrikagrense, ook hier tov Suidwes-Afrika, vasgestel is, het tot onvermydelike geskille, soos bv by die Walvisbaaigebied en langs die oosgrens, aanleiding gegee. $\mathrm{Lg}$ wat onderskeidelik die $20^{\circ}-21^{\circ}$-lengtelyn asook die $22^{\circ}$-breedtelyn volg begin in die suide by die Oranjerivier en strek tot by die "winkelhaak" ( $18^{\circ}$ $18,5^{\prime} \mathrm{S}$ ) in die noorde - ' $\mathrm{n}$ totale grenslengte van 1240 kilometer. Ook die grense van NoordSuidwes-Afrika en die Caprivistrook was nie sonder interpretasieprobleme nie. Aangesien Ig binne die brandpunt van huidige militêre bedrywighede val, sal meer aandag aan hierdie grense gegee word. (Kyk figuur 1).

\section{Die noordgrens en die Caprivistrook}

\section{(a) Die Noordgrens}

Hierdie grens wat tans Angolese van SuidwesAfrikaanse grondgebied skei, is deur 'n deklarasie, wat deur verteenwoordigers van Portugal en Duitsland op 30 Desember 1886 onderteken is, bepaal. Hierdie dokument het die grens vanaf die monding van die Kunene tot sover oos as die Katima Mulilo-stroomversnellings op die Zambesi-rivier omskryf. Artikel I van die deklarasie lui dat die grenslyn tussen die Portugese en Duitse besittings in Suidwes-Afrika die loop van die Kunenerivier volg vanaf sy monding tot by die stroomversnellings wat suid van Humbe gevorm word waar hierdie rivier deur die Canna-heuwelreeks breek. Vanaf hierdie punt loop hierdie 
SUIDWES - AFRIKA / NAMIBIË

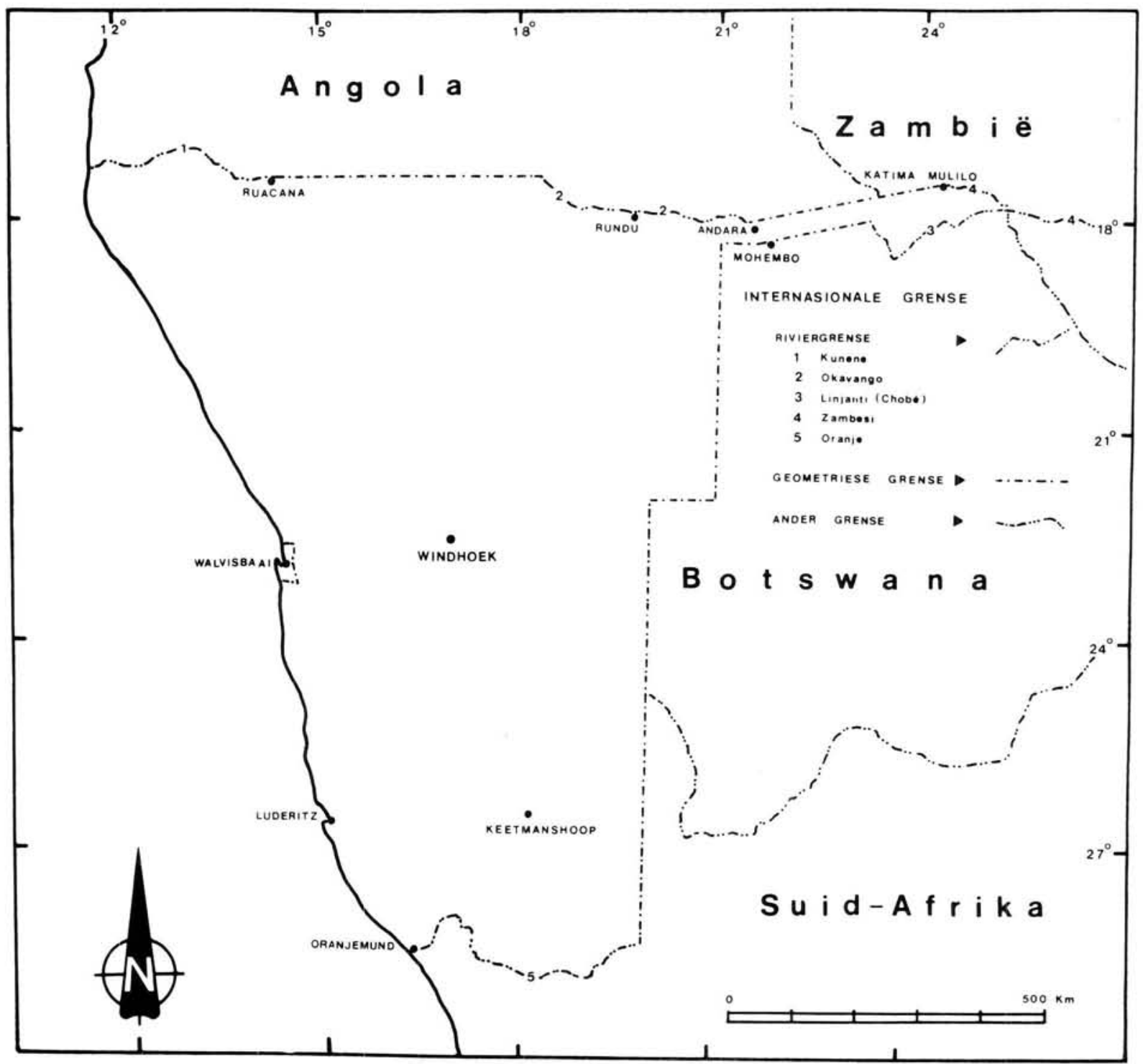

Figuur 1: Die grense van Suidwes-Afrika

grens al langs 'n breedtelyn (17 $23^{\prime}$ 'S) tot by die Kubango-(Kavango-)rivier en dan in die loop van hierdie stroom tot by Andara $\left(21^{\circ} 26,5^{\prime} \mathrm{O}\right.$ en $\left.18^{\circ} 04^{\prime} \mathrm{S}\right)$. Vanaf Andara sou die grenslyn direk in 'n ooswaartse rigting tot by die Katima-versnellings in die Zambesirivier strek (Brownlie 1979; 1028).

Die Anglo-Duitse Ooreenkoms van 1 Julie 1890 het die Zambesiriviergedeelte, vanaf Katima Mulilo in die weste tot by die Linjantirivieraansluiting in die ooste, bepaal. Hiermee het Duitsland toegang tot die Zambesi verkry "by a strip of territory which shall at no point be less that 20 English miles in width" (Kyk Brownlie 1979; 1289)
Die 1886-verklaring was nie duidelik tov die betrokke waterval(le) in die Kunenerivier nie. In die praktyk was daar geen duidelike verwysing na die presiese punt waarvandaan die breedtegraadgrens ooswaarts neergelê moes word nie. $\mathrm{Na}$ die besetting van Suidwes-Afrika in 1915 het die Britse en Portugese administrasies ' $n$ voorlopige ooreenkoms (1916) gesluit waardeur 'n ses myl wye neutrale sone geskep is wat dan ook gesamentlik geadministreer sou word. Verdere samesprekings is in 1919-20 oor dié aangeleentheid gevoer. Op 22 Junie 1926 het 'n verdere ooreenkoms gevolg wat die aangeleentheid finaal opgelos het. Op grond van die vergelyk is die grens (in soverre dit prakties moontlik 


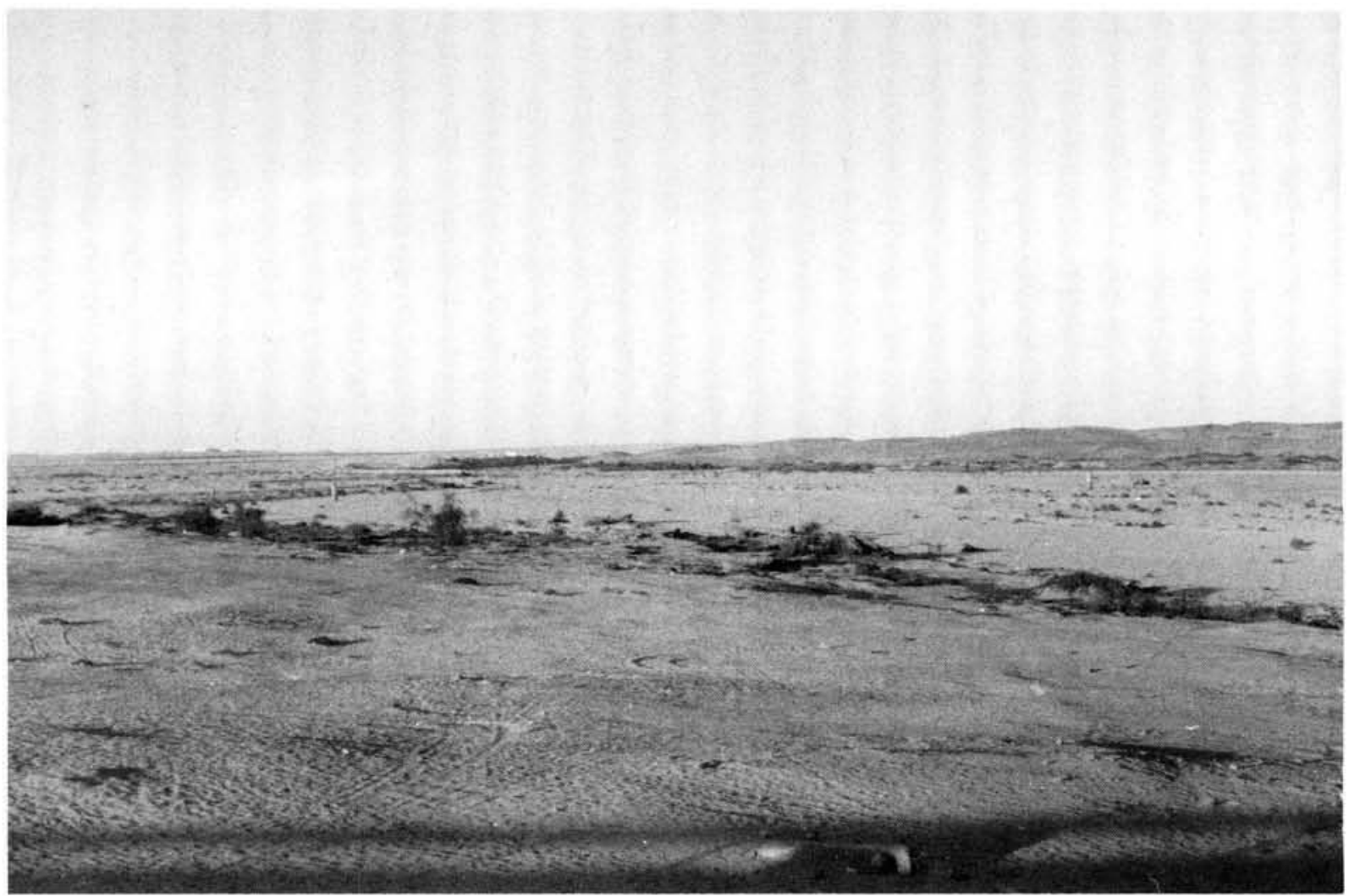

Die Walvisbaaigebied, 'n eksklawe van die Republiek van Suid-Afrika, word in die noorde dmv die droë Swakoprivierloop van Suidwes-Afrika geskei.

was) afgebaken. Die grens wat op hierdie wyse tot stand gekom het is op 29 April 1931 deur 'n notawisseling goedgekeur (Kyk hieronder).

In die 1926-ooreenkoms is aanvaar dat die waterval waarna in die 1886-traktaat verwys is die Ruacana (soos aangeteken op Portugese kaarte) of Kambele (soos dit op Duitse kaarte verskyn het) wat op ongeveer $17^{\circ} 23^{\prime} \mathrm{S}$ geleë was, sou wees. Vanaf die monding tot by die Ruacanaval sou die aangewese grens die mediaanlyn ("... the middle line ..., that is to say, the line drawn equidistant from both banks...") wees tot waar die vermelde lyn die $17^{\circ} 23^{\prime}$ suiderbreedtelyn kruis. 'n Baken is op die oostelike (of linkeroewer) van die Kunene geplaas om die plek aan te dui waar die betrokke breedtelyn die rivier kruis.

In die afbakening van die geometriese grens tussen die Kunene- en Kavangorivier is ooreengekom dat permanente bakens opgerig sou word wat nie verder as 10 kilometer van mekaar sou wees nie. Daar is ook onderneem om "minder permanente" bakens aan te bring waar paaie, voetpaaie, riviere, strome en "oshanas" en "mololas" die grens sou kruis. Terselfdertyd

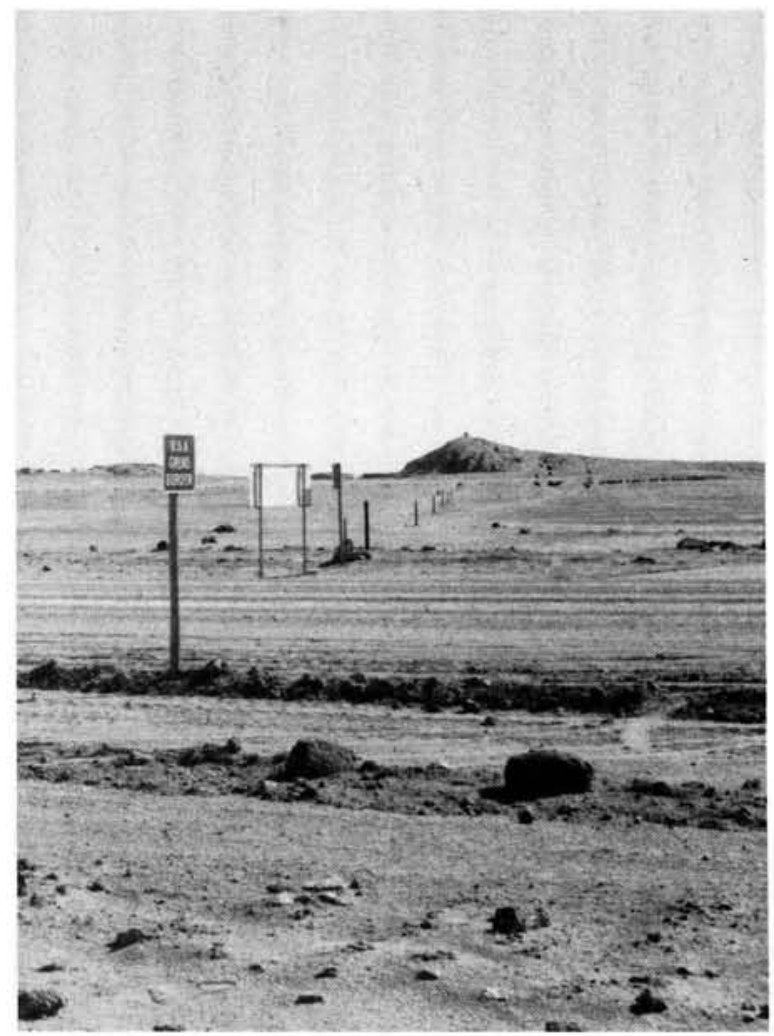

Pale en sandgevulde konkas vorm die geometriese grenslyn tussen die Walvisbaaigebied en Suidwes-Afrika digby die LMB Rooikop. 
sou die grenslyn skoongehou en bosse en bome verwyder word. Daar is ook ooreengekom om die ses myl wye neutrale sone waarna reeds hierbo verwys is te behou totdat die afbakening van die grens (tussen die Kunene en die Okavango) voltooid was (Brownlie 1979; 1026-1030). Die kaplyn soos dit vandag bekend is het dus in 1926 eerste beslag gekry!!

Die gesamentlike kommissie wat die grensafbakening uitgevoer het, het na voltooiiing van hul opdrag verklaar dat 47 bakens* (wat dmv koorde verbind is) tussen die Kunene en Okavango opgerig is. Die eerste baken is op die linkeroewer van die Kunene geplaas op die presiese plek waar die eerste baken in 1920 deur die kommissie wat deur Brittanje en Portugal aangewys is, opgerig is. Baken 47 is op die regteroewer $\left( \pm 18^{\circ} 25^{\prime} \mathrm{Oos}\right)$ nagenoeg $36,8 \mathrm{~km}$ noord-noordwes van Kuring Kuru geplaas (Brownlie 1979; 1027; 1033). Green (1981; 168) verwys na hierdie deel van die noordgrens soos volg: "The South West-Angola border forms the longest direct road in Africa, for it runs arrowstraight from the Rua Cana Falls to a point on the Okavango River - a distance of 275 miles. This road twenty feet wide has been cut through the bush; and from the air it looks like a white line. Every six miles there is a concrete beacon on which Ovambo warriors sharpen their spears. This is one of Africa's dramatic boundaries."

Soos reeds voorheen vermeld volg die grens vanaf Kakeri die middel van die Kavangorivier tot in die omgewing van Andara.

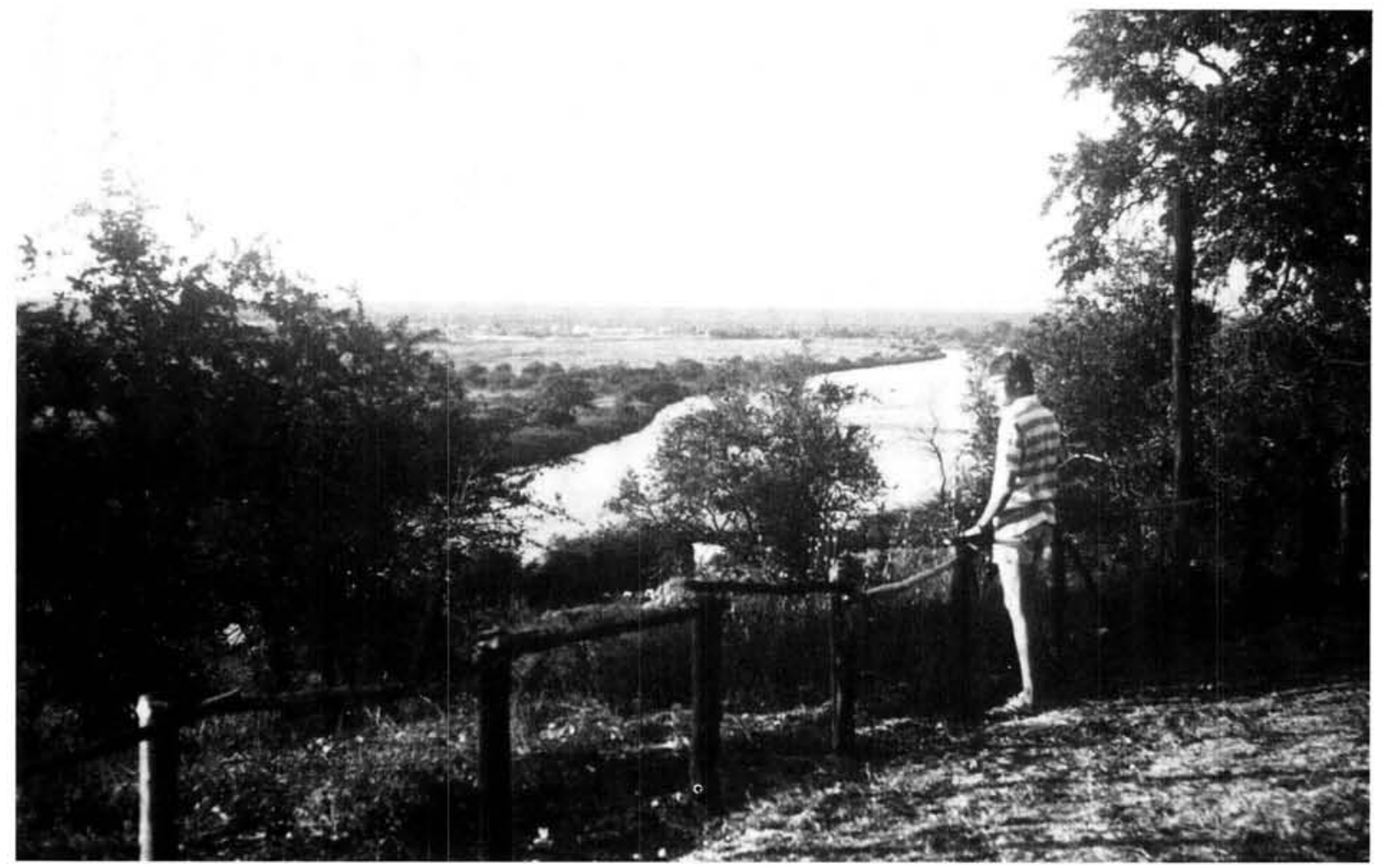

Die Okavangorivier vorm vir 'n gedeelte van die grens tussen Angola en Suidwes-Afrika. Hierdie foto is by Rundu geneem. In die agtergrond lê die nou verlate Angolese dorpie, Calai.

\section{(b) Die Caprivistrook}

Die 1886-beskrywing van die verwysingspunte oos van Andara in die rigting van Katima Mulilo was nie baie presies nie, met die gevolg dat 'n gesamentlike grenskommissie hierdie grenssektor in 1930-31 heropgemeet en afgebaken het. Hierdie afbakening is op 16 Augustus 1931 tussen verteenwoordigers van Portugal, die Unie van Suid-Afrika en Noord-Rhodesië (Zambië) onderskryf (Brownlie 1979; 1027, 1291). Daar is egter geen bewys dat hierdie reëling die goedkeuring van die Raad van die ou Volkerebond verkry het nie.

Volgens ooreenkoms sou hierdie reguit grenslyn vanaf die noordelikste punt van Sibanana-eiland in die Okavangoriviér tot in die middel van die

Aan die noorde- en suidekant van elke baken is onderskeidelik die name Angola en SWA aangebring, terwyl die nommer op die westekant aangedui is. 
Katimastroomversnellings in die Zambesirivier loop. Dertig bakens is aangebring om die ligging van die grenslyn aan te dui. Die westelike baken is op 'n groot rots aan die westelike rand van die Dikuju-eiland in die Okavangorivier opgerig op $21^{\circ} 25^{\prime} 28,81^{\prime \prime}$ Oos en $18^{\circ} 01^{\prime} 32,75^{\prime \prime}$ Suid. Die mees oostelike baken (24. $14^{\prime} 50,04^{\prime \prime}$ Oos en $17^{\circ} 28^{\prime} 29,28^{\prime \prime}$ Suid) is op die westekant (regteroewer) van die Zambesi by die Katimastroomversnellings geplaas om aan te toon waar hierdie grens die rivier binnegaan.

Tussen die Dikuju-eilandbaken en die Kwandoof Mashirivier is 23 bakens opgerig, terwyl nog sewe tussen die vermelde rivier en Katima Mulilo aangebring is. Onsekerheid het egter bestaan oor presies waar die grens die Kwandorivier moes kruis. Hierdie driepunt, presies daar waar die grondgebied van Angola, Zambië en Suidwes-Afrika bymekaarkom, is eers op 18 November 1954 deur Anglo-Portugese verdrae bepaal en op 21 Oktober 1964 nav notawisseling deur die Suid-Afrikaanse regering aanvaar (Kyk Brownlie 1979: 1027. 1292-1294).

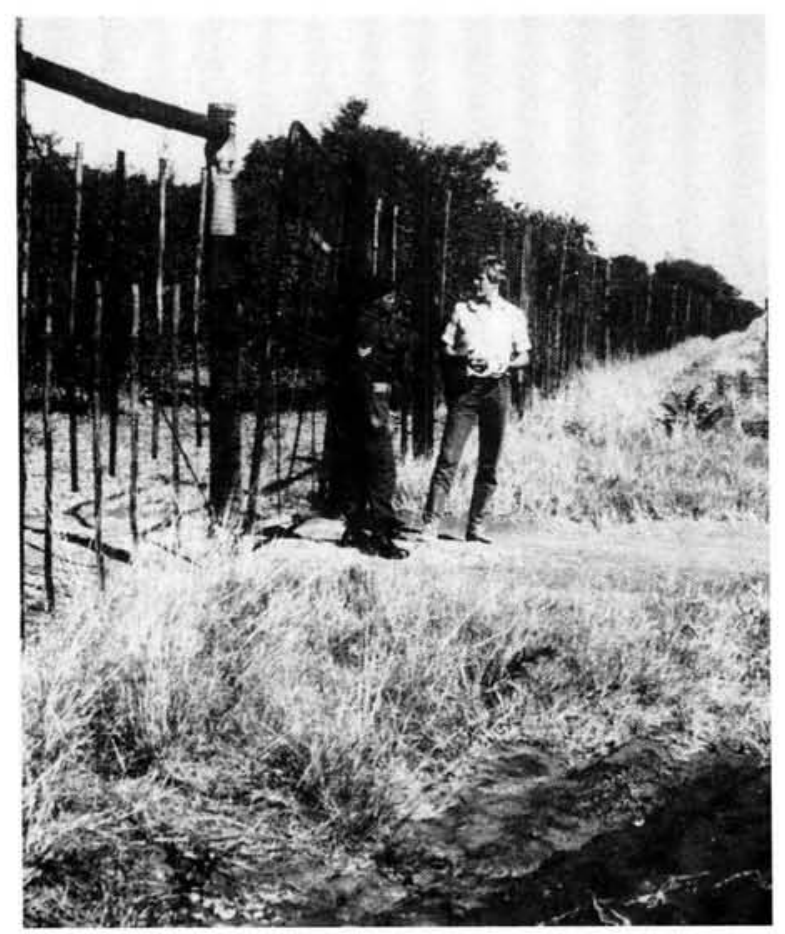

Die suidelike geometriese grenslyn ('n skuinslyn) van die Caprivistrook. Hierdie foto is by die Mohembohek digby die Okavangorivier geneem.

Briefwisseling (4 Julie en 25 Julie 1933) tussen generaal J.B.M. Hertzog as eerste minister van Suid-Afrika asook mandaathouer oor Suid-Afrika en die Britse hoë kommissaris het basies erkenning verleen aan die grensvasstelling tussen Noord-Rhodesië (Zambië) en Suidwes-Afrika oos van die Katimastroomversnellings. Die hoofkanaal, of "thalweg" van die Zambesi tot by sy samevloeiing met die hoofkanaal van die Chobe- of Linjantirivier is as grens aanvaar. Verder is bepaal dat die eiland in dié rivier wat aan die Caprivikant van die thalweg geleë was aan Suidwes-Afrika sou behoort en dié aan die anderkant Zambiese besit sou wees (Brownlie $1979 ; 1295)$. Die vasstelling van die presiese ligging van die hoofkanaal, veral in ' $n$ rivier soos die Zambesi waarin baie eilande voorkom, is nie sonder probleme nie. Gewoonlik moet bepaal word watter van die talle vertakkinge, tussen die eilande deur, die grootste watervolume, die diepste bodem en die grootste stroomsnelheid het. Die takstroom met hierdie eienskappe word as die hoofstroom of "thalweg" beskou (Barnard 1959; 234).

Die presiese punt waar die hoofkanale van die Zambesi- en die Choberivier mekaar ontmoet, het in die vroeë 1970 sterk na vore getree toe die bou van 'n pad tussen Botswana en Zambië oor Kazangula geopper is. So ' $n$ moontlikheid het ter sprake gekom toe die VSA by monde van mnr William Rogers, sy minister van Buitelandse Sake hul bereid verklaar het om deur die Agency for International Development (AID) \$ 6 miljoen vir so 'n padbouprogram beskikbaar te stel (Keesings 1970; 24128). Die Suid-Afrikaanse regering het hierop gereageer deur ' $n$ nota aan die regering van Botswana te stuur waarin dit duidelik gestel is dat daar volgens hierdie regering geen gemeenskaplike grens tussen Botswana en Zambië bestaan nie (Bulletin 1970; 198). Die Botswanaregering het egter verklaar dat daar na hul mening wel ' $n$ gemeenskaplike grens bestaan en "that such a road would in no way alter the status quo since it simply improves access to the Kazangula ferry which has been operating unchallenged for many years" (Keesing's 1970; 24128. Kyk ook East and Prescott 1975; 60 en figuur 2).

In Januarie 1885 het die Britse regering Duitsland in kennis gestel dat Betsjoeanaland (Botswana) onder sy (Brittanje) beskerming geplaas is. Die totstandkoming van die Betsjoeanalandprotektoraat het dus ook die omskrywing van sy grense, insluitend die met Suidwes-Afrika, en in besonder die grens met die Caprivistrook, vereis. Die Anglo-Duitse Verdrag wat op 1 Julie 1890 tot stand gekom het, het onder andere bepaal dat ' $n$ gedeelte van die oosgrens van Suidwes-Afrika die $21^{\circ}$-Oosterlengtelyn sou volg tot by die kruising van die $18^{\circ}$-Suiderbreedtelyn. Daarvandaan ooswaarts sou dit die betrokke 


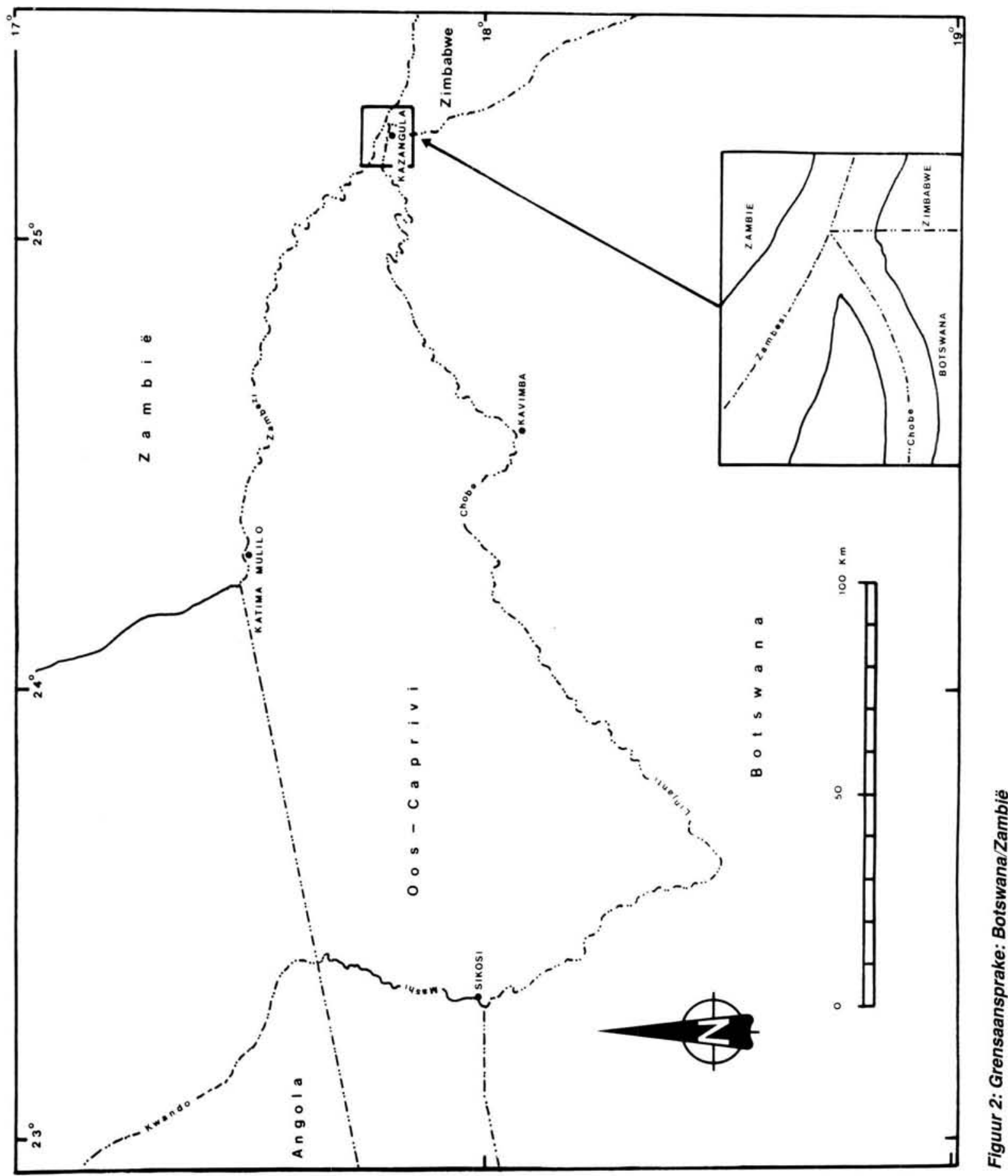

breedtelyn volg totdat dit die Choberivier bereik en dan met die middel van die hoofkanaal loop totdat dit by die Zambesirivier aansluit. Voorts is ook aanvaar dat Duitsland vrye toegang vanaf sy grondgebied (Duitswes-Afrika) na die Zambesi sou hê en dat hierdie strook nêrens minder as $20 \mathrm{myl}$ (32 kilometer) in die wydte sou wees nie (Brownlie 1979; 1075).

Die Anglo-Duitse grensdefinisie van 1 Julie 1890 het na enkele jare geblyk foutief te wees. Andara wat op $18^{\circ} 04^{\prime}$ Suiderbreedte en binne SuidwesAfrika geleë is sou buite hierdie gebied geval het indien die suidgrens van die Caprivi wel in daardie omgewing die $18^{\circ}$-Suiderbreedtelyn sou volg. Per implikasie sou Portugese (Angola) en Britse (Betsjoeanaland) grondgebied mekaar dan oorvleuel het. Op die wyse sou DuitswesAfrika toegang tot die Caprivistrook ontsê word (East and Prescott 1975; 60). Volgens Duitsland het die Caprivisuidgrens tussen $21^{\circ}$ Oos en die Linjantirivier ' $n$ breedtelyn gevolg wat deur ' $n$ 
punt presies 20 myl (32 kilometer) suid van Andara gesny het. Volgens Brittanje se mening moes hierdie grens presies 20 myl suid van die Duits-Portugese (Angola-Suidwes-Afrika-) grens geplaas word (Prescott 1979; 9). Moderne kaarte toon die grens tussen die Caprivi en Botswana aan as beginnende by $18^{\circ} 18,5^{\prime}$ S en $21^{\circ}$ $00^{\prime} \mathrm{O}$. Hiervandaan volg dit die $18^{\circ} 18,5^{\prime}$ breedtelyn tot by Vilnoa $\left( \pm 21^{\circ} 29,5^{\prime} O\right)$. ' $n$ Skuinslyn verbind hierdie punt met 'n posisie $23^{\circ} 06^{\prime} \mathrm{O}$ op die $18^{\circ}$-breedtelyn. Van hier loop die grens langs hierdie betrokke lyn totdat die Linjantirivier (Chobe) bereik word. Soos reeds voorheen vermeld volg die grens die middel van die hoofkanaal totdat dit by die Zambesirivier aansluit.

\section{Slotopmerkings}

Die grense van Suidwes-Afrika, wat deur verskillende verdrae hul beslag gekry het, het deur die jare permanensie verwerf. Uit die voorafgaande het dit duidelik geword dat die vasstelling van hierdie skeidslyne nie sonder probleme gepaard gegaan het nie. Die praktyk het egter ook getoon dat van hierdie "nuwe" grenslyne ontwrigtend op die plaaslike bevolking ingewerk het. Barnard (1959; 235-237) haal enkele voorbeelde in die verband aan. Onder andere meld hy dat die inwoners van Noordwes-Ovamboland in tye van droogte hul vee na die Kunene gejaag het. Stroom-af van die Ruacanaval is die kloof egter so steil dat die rivier bykans onbereikbaar is. Die destydse Unieregering moes daarom in 1929 spesiale onderhandelings met die Portugese regering aanknoop om verlof te bekom sodat die Ovambo's hul beeste oor die grens (na Angola) kon neem waar die rivierwater meer bereikbaar is.

Die grootste Ovambostam, die Ukuanjama word ook deur die geometriese noordgrens tussen Angola en Suidwes-Afrika verdeel. Barnard (1959; 237) meld dat beweging (ook van drank en ammunisie) vryelik oor hierdie grens plaasgevind het sodat dit nie veel van ' $n$ skeiding was nie. Van al die bevolkingsgroepe is dit juis die Ovambo wat die meeste deur die noordgrens ontwrig word. Twee derdes van hulle bevind hulself in Suidwes-Afrika en die ander derde in Angola. In die praktyk het die Ovambo's en hul beeskuddes die grensgedeelte tussen Ruacana en die Kavango tot die 1970's bykans ongehinderd oorgesteek (Barnard 1985; 194). As gevolg van vyandelikhede tussen die Suid-Afrikaanse Weermag en die Suidwes-Afrikaanse gebiedsmag aan die een kant en SWAPO aan die anderkant, word grenskruisings sedert 1975 aan bande gelê. SWAPO-insypelings suid van die grens duur egter voort.

Die 1520 km-lange grenslyn tussen die Kunenemonding in die weste en Kazangula langs die Zambesi in die ooste verdeel vier Afrika-taalgroepe, naamlik Oshihirero-sprekendes aan weerskante van die Kunene, die Ovambo's waarna reeds hierbo verwys is, verwante stamgroepe aan beide kante van die Okavangorivier en Silozi-sprekendes naby die samevloeiing van die Linjanti- en Zambesirivier (Barnard 1985; 194).

Omdat oppervlaktewater in Suidwes-Afrika skaars is, het veral 'n rivier soos die Okavango 'n swak grens geblyk te wees daar beide oewers dig bewoon was. Vroeër was daar ook ' $n$ taamlike verkeer oor die rivier, dikwels van Angolainwoners wat vir mediese behandeling na hospitale in Suidwes-Afrika gekom het. Die Mbukushu-stam, wat vroeër die eilande by die stroomversnellings van Andara bewoon het, moes egter agv die grensreëlings hul tuistes ontruim sodat hul vandag aan die suidoewer woon (Barnard 1959; 236).

Ook in die Caprivistrook het die totstandkoming van 'n grens sy invloed op die plaaslike bevolking laat geld. Die inwoners van die gebied het oorspronklik onder gesag van die Barotseopperhoof van Zambië gestaan. Omdat beide kante van die rivier bewoon was, het die inwoners daaraan gewoond geraak dat hul vee gedurende die droë seisoen op die riviereilande kon wei. Met die grensreëling van 1933 toe hierdie eilande aan onderskeidelik Zambië (Noord-Rhodesië) en Suidwes-Afrika toegeken is, is die inwoners van die gebied swaar getref. Om hierdie rede het die Unieregering as mandaathouer van Suidwes-Afrika sy toestemming verleen "... that natives of Northern Rhodesia may be allowed to exercise the privilege of cultivation, hunting, fishing and of cutting poles and reeds in certain of the Caprivi islands" (Barnard 1959; 236, 237 en Brownlie 1979; 1295).

Uit die bostaande paragrawe het dit duidelik geword dat die grense van Suidwes-Afrika en veral die noord- en Caprivigrense arbitrêr en kunsmatig van aard is. Etno-linguïstiese oorwegings by die vasstelling van hierdie skeidslyne het weinig of geen oorweging geniet nie. Menslike besluitneming, hoewel baie jare gelede, het eintlik hierdie onnatuurlike situasie bewerkstellig deurdat mense wat dieselfde taal praat en dikwels dieselfde ekonomiese aktiwiteite beoefen 
van mekaar geskei word. Alhoewel grense die soewereiniteit van state skei weerhou dit gewoonlik nie die inwoners van die verskillende lande om daaroorheen te beweeg nie. Bewegings word egter aan bande gelê wanneer beheer, hetsy deur mure, draadversperrings, wagte, ens, streng toegepas word om hierdie "grensskendings" te voorkom. Skeidings waar ekonomiese, etniese en taalkundige beweegredes nie in ag geneem is nie, kom egter wêreldwyd voor en is nie slegs ' $n$ probleem wat Afrikagrense raak nie (Pfaff 1985; 69).

"Kol J.C. Kotzé is sedert 1 Mei 1981 dekaan van die Fakulteit Krygskunde. Sy akademiese kwalifikasies is Hons BA; MA; D Phil en SOD. Voor sy aanstelling as dekaan was hy dosent in Militêre Geografie.

\section{Bibliografie:}

Barnard, W.S., 1959: Staatkundig-Geografiese Aspekte van Suidwes-Afrika. MA-tesis, Universiteit van Stellenbosch.

Barnard, W.S., (red), 1985: Kompas op Suidwes-Afrika/Namibië. Vereniging vir Geografie. Spesiale Publikasie Nr 5 1985, Dennesig.
Barnard, W.S., 1985: The Border War: After 19 years. In Barnard (red), 1985. Brownlie, I., 1979: African Boundaries. A Legal and Diplomatic Encyclopaedia. C. Hurst and $\mathrm{Co}$, London.

Bulletin, Afrika-Instituut van Suid-Afrika, Junie 1970, Deel 10, Nr 5, Pretoria.

East, W.G. and Prescott, J.R.V., 1975: Our Fragmented World. An Introduction to Political Geography. The MacMillan Press Ltd, London and Basingstoke.

Europa Publications Ltd, 1985: The Europa Year Book 1985. A World Survey, Volume 2.

Green, L.G., 1981: Lords of the last Frontier. Howard timmins Pubs, Cape Town, Salisbury, etc.

Keesing's Contemporary Archives, volume No XVII, 1969-1970. Keesing's Pubs Ltd, Bristol.

Odendaal, F.H. (voors), 1963: Verslag van die Kommissie van Ondersoek na Aangeleenthede van Suidwes-Afrika 1962-1963. Die Staatsdrukker, Pretoria.

Pfaff, D.F., 1985: Afrika se grense. 'n Histories-kritiese beskouing. Bulletin van die Afrika-Instituut van Suid-Afrika, Vol 25, Nr 6 en 7, 1985, Pretoria.

Pounds, N.J.G., 1972: Political Geography. McGraw-Hill Book Co, New York, Johannesburg etc

Prescott, V., 1979: Africa's Boundary Problems. Optima, Vol 26. Nr 1.

Rake, A. (ed), 1984: New African Yearbook 1984-85. IC Magazines Ltd, London.

Stals, E., 1985: Suidwes-Afrika/Namibië en die Imperialistiese Stormloop om Afrika. In Barnard (red), 1985.

Touval, S., 1972: The Boundary Politics of Independent Africa. Harvard University Press, Cambridge, Massachusetts.

Van der Spuy, D.C. (hoofred), 1977: Suid-Atrika 1977. Amptelike Jaarboek van die Republiek van Suid-Afrika. Perskordrukkery, Johannesburg.

Wellington, J.H., 1967: South West Africa and its Human Issues. Clarendon Press, 0xford. 